Original Research Article

\title{
Antibiotic susceptibility pattern of bacteria isolated from patients of respiratory tract infection in a tertiary care hospital of Central India
}

\author{
Shilpi Dhakre', Pooja Reddy ${ }^{2 *}$, Mohit Kulmi², Chhaya Goyal $^{2}$
}

${ }^{1}$ Department of Pharmacology, Maharajah's Institute of Medical Sciences, Nellimarla,

Vizianagaram, Andhra Pradesh, India

${ }^{2}$ Department of Pharmacology, Sri Aurobindo Medical College and Postgraduate Institute, Indore, Madhya Pradesh, India

Received: 02 May 2017

Accepted: 27 May 2017

*Correspondence to:
Dr. Pooja Reddy,
Email: drpoojasreddy @
gmail.com

Copyright: (C) the author(s), publisher and licensee Medip Academy. This is an openaccess article distributed under the terms of the Creative Commons Attribution NonCommercial License, which permits unrestricted noncommercial use, distribution, and reproduction in any medium, provided the original work is properly cited.

\begin{abstract}
Background: Respiratory tract infections are one of the commonest types of infections affecting the Indian population and are a significant cause of morbidity and mortality. To deal with multidrug resistance one should be armed with region specific data about the susceptibility patterns of antimicrobials. This study was planned to identify the common pathogens responsible for the respiratory tract infection and their antibiotic susceptibility patterns.

Methods: Smears were prepared from the specimens and gram stains of all clinical samples were done. The organisms were grown on various media and identified according to the standard procedures. The susceptibility patterns of the bacterial pathogens were determined following the panel of antimicrobial agents. Descriptive statistics were used for data analysis.

Results: Out of 513 samples 471 samples were further processed. Klebsiella $(30.42 \%)$ was found to be commonest pathogen followed by Pseudomonas $(28.36 \%)$. Ampicillin and piperacillin /tazobactam combination were found to be highly efficient against Pseudomonas (83\% and 58.8\% respectively), E. coli (68\% and $50.7 \%$ respectively), and Klebsiella (43\% and $30.3 \%$ respectively).

Conclusions: In our study, we found penicillins as the most efficacious antimicrobials to treat respiratory pathogens. The study reveals that the antibiotic susceptibility pattern varies across regions. The prescription of a right antibiotic, for a right patient will help to minimize the menace of emergence of antimicrobial resistance.
\end{abstract}

Keywords: Drug resistance, Respiratory tract infections, Susceptibility pattern

\section{INTRODUCTION}

Respiratory tract infections are one of the commonest types of infections affecting the Indian population with prevalence rates ranging around 52\%. ${ }^{1}$ Respiratory infections, particularly those affecting the lower respiratory tract, are significant causes of morbidity and mortality. ${ }^{2}$ The majority of antibiotics prescribed in general practice are for respiratory tract infections (RTIs). ${ }^{3,4}$ The incidence, etiology and prognosis vary depending on age, concurrent illness and predisposing risk factors as well as on whether such infections are community or hospital acquired. ${ }^{5-8}$ To add to the trouble, statistical data and evidences from researches prove that multidrug resistance bacteria are rapidly emerging across the world and pose a big challenge to health care. Multidrug resistant bacteria cause serious nosocomial and community acquired infections that are hard to eradicate using available antibiotics. Extensive and non-specific use of broad spectrum antibiotics in hospitalized patients has led to both increased carriage and the development of multidrug - resistant strains that produce extended spectrum beta-lactamase (ESBL) ${ }^{9}$

Although the antimicrobial resistance has increased over a period of time, the development of novel antimicrobial agents has dramatically declined over the past 30 years. ${ }^{10}$ 
Therefore, to prevent the return of the pre-antibiotic era, one must use existing antibiotics skillfully and more judiciously. It's difficult to manage these infections effectively unless we are armed with adequate and good quality data about the antibiotics susceptibility patterns of organisms causing respiratory tract infections. To be effective, this data has to be region specific and also has to be updated regularly as bacterial susceptibility varies across time and space. Unfortunately, such a data is scant and this has led to a wide spread morbidity and mortality due to respiratory infections in central India. Hence, the study was planned to identify the common pathogens responsible for the respiratory tract infection and their antibiotic susceptibility patterns.

\section{METHODS}

The present study was conducted at Sri Aurobindo Institute of Medical Sciences, Indore. The participants of the study were all the patients of lower respiratory tract infection admitted in the Intensive Care Unit of Hospital during January 2015 to December 2016. After the due written informed consent from the participants or their guardian, the Lower Respiratory Tract (LRT) samples such as sputum, suction tip, endotracheal aspirate, bronchial aspirate and pleural fluid were obtained under aseptic precautions and were processed immediately. Macroscopic appearance of the sample was noted for color, consistency, quantity, and for presence of any pus or blood. Smears were prepared from the specimens and gram stains of all clinical samples were examined under compound microscope using oil immersion objective lens. The smear was examined for presence of pus cells, lymphocytes and epithelial cells. Gram reaction and arrangement of bacteria was seen.

Each sample was inoculated on blood agar and MacConkeys agar and incubated at $37^{\circ} \mathrm{C}$ for 24 hours and further for 48 hours if necessary, the organisms grown were identified on basis of their morphology, cultural characters and biochemical reactions according to standard procedures. Isolates from repeat culture of previously recruited patients and isolates identified as commensals or contaminants were excluded. The bacterial isolates were subjected to susceptibility testing by standard Kirby Bauer disc diffusion methods. ${ }^{4}$ The susceptibility patterns of the bacterial pathogens were determined following the panel of antimicrobial agents as recommended by Clinical Laboratory Standard Institute (CLSI) $-2010 .^{11}$

\section{Preparation of plates}

Muller Hilton agar (Hi-Media) was prepared from a commercially available dehydrated base according to manufacturer's instructions and was used for antimicrobial susceptibility testing. Representative sample of each batch of plates was examined for sterility by incubating at $35-37^{\circ} \mathrm{C}$ for $16-18$ hours or longer.
Before inoculation; plates were dried with lids ajar so that no moisture droplets were present on the agar surface.

\section{Preparation of inoculums}

At least 3-5 well-isolated, morphologically similar colonies from an agar medium were touched with a straight wire loop and growth was transferred to a test tube containing $4-5 \mathrm{ml}$ of sterile peptone water. The tubes were incubated for 2 to $6 \mathrm{hrs}$ at $37^{\circ} \mathrm{C}$ to produce a bacterial suspension of moderate cloudiness.

\section{Inoculation}

Plates were inoculated within 15 minutes of preparation of suspension so that the density does not change. A sterile cotton swab was dipped into the suspension and surplus removed by rotation of the swab against the side of the tube above the fluid level. The medium was inoculated by even streaking of the swab over the entire surface of the plates in three directions.

\section{Applications of antibiotic discs}

Antibiotic discs were stored at $4^{\circ} \mathrm{c}$ in refrigerator. The discs were allowed to come to room temperature before application. After the inoculated plates were dried antibiotic discs were applied to the agar surface with a sterile forceps and gently pressed down to ensure contacts. They were distributed evenly so that they were not closer than $24 \mathrm{~mm}$ from centre to centre. not more than 8 discs were applied on $90 \mathrm{~mm}$ plate. Concentration of antibiotics used for testing susceptibility according to CLSI guidelines. ${ }^{11}$

Zone diameter was measured in millimeters and interpreted as per CLSI guidelines. ${ }^{12}$ The identification of the bacterial isolates up to species level and their antimicrobial susceptibilities were also confirmed using Vitek 2 compact (BioMérieux, France). The entire testing was done under strict quality control and American Type Culture Collection (ATCC) strains were used as control strains.

\section{RESULTS}

Four hundred and twenty-three patients participated in the study and 513 samples were received in the microbiology department. Forty-two samples were excluded due to reasons such as contamination, inadequate quantity and poor labeling and the rest 471 samples were further processed. The samples obtained were from tracheal swab, endotracheal tube, pleural fluid, throat swab and sputum and their percentage distribution was as stated in Table 1.

The discriminative prevalence of various organisms across the sample site was assessed and Klebsiella $(30,42 \%)$ was found to be commonest pathogen isolated from all the sites followed by Pseudomonas (28.36\%) as 
the next common pathogen isolated across all the sites. The discriminative prevalence of rest of the organisms in the decreasing order were Staphylococcus (14.89\%), E. coli $(10.93 \%)$, Acinetobacter (9.82\%), Enterobacteriace (2.85\%), Streptococcus $(1.74 \%)$ and Enterobacter $(0.95 \%)$. Klebsiella was the most prevalent organism isolated from Trachea (31.05\%), Endotracheal $(30.40 \%)$ and Sputum $(32.08 \%)$ where as in pleural fluid sample Pseudomonas was the most prevalent $(30.76 \%)$ and in throat swab Staphylococcus was the most prevalent $(42.85 \%)$ organism isolated (Table 2$)$.
Table 1: Number and percentage distribution of various samples.

\begin{tabular}{|lll|}
\hline & Samples obtained & $\mathbf{N}(\%)$ \\
\hline 1. & Tracheal & $140(29.7 \%)$ \\
\hline 2. & Endotracheal & $129(27.3 \%)$ \\
\hline 3. & Pleural fluid & $21(4.4 \%)$ \\
\hline 4. & Throat swab & $18(3.8 \%)$ \\
\hline 5. & Sputum & $163(34.6 \%)$ \\
\hline Total specimens & 471 \\
\hline
\end{tabular}

Table 2: Discriminative prevalence of isolated organisms.

\begin{tabular}{|c|c|c|c|c|c|c|}
\hline $\begin{array}{l}\text { Type of } \\
\text { organism }\end{array}$ & Tracheal & Endotracheal & Pleural fluid & $\begin{array}{l}\text { Throat } \\
\text { swab }\end{array}$ & Sputum & $\begin{array}{l}\text { Total } \\
\text { n }(\%)\end{array}$ \\
\hline Staphylococcus & $34(15.52 \%)$ & $23(13.45 \%)$ & $03(11.53 \%)$ & $12(42.85 \%)$ & $22(11.76 \%)$ & $94(14.89 \%)$ \\
\hline Streptococcus & Nil & $01(0.58 \%)$ & Nil & Nil & $10(5.34 \%)$ & 11(1.74\%) \\
\hline Pseudomonas & $66(30.13 \%)$ & $46(26.90 \%)$ & $08(30.76 \%)$ & $06(21.42 \%)$ & $53(28.34 \%)$ & $179(28.36 \%)$ \\
\hline Klebsiella & $68(31.05 \%)$ & $52(30.40 \%)$ & $05(19.23 \%)$ & $07(25 \%)$ & $60(32.08 \%)$ & $192(30.42 \%)$ \\
\hline Acinetobacter & $21(9.58 \%)$ & $32(18.71 \%)$ & $02(7.69 \%)$ & Nil & $07(3.74 \%)$ & $62(9.82 \%)$ \\
\hline E. coli & $22(10.04 \%)$ & $13(7.60 \%)$ & $06(23.07 \%)$ & $03(10.71 \%)$ & $25(13.36 \%)$ & $69(10.93 \%)$ \\
\hline Enterobacter & $02(0.91 \%)$ & $02(1.16 \%)$ & Nil & Nil & $02(1.06 \%)$ & $6(0.95 \%)$ \\
\hline Enterobacteriace & $06(2.73 \%)$ & $02(1.16 \%)$ & $02(7.69 \%)$ & Nil & $08(4.27 \%)$ & $18(2.85 \%)$ \\
\hline Total & 219 & 171 & 26 & 28 & 187 & 631 \\
\hline
\end{tabular}

Table 3: Susceptibility patterns of pathogens causing respiratory tract infection.

\begin{tabular}{|c|c|c|c|c|c|c|c|c|}
\hline & $\begin{array}{l}\text { Staphylococcus } \\
(\mathrm{n}=94)\end{array}$ & $\begin{array}{l}\text { Streptococcus } \\
(\mathrm{n}=11)\end{array}$ & $\begin{array}{l}\text { Pseudomonas } \\
(\mathrm{n}=179)\end{array}$ & $\begin{array}{l}\text { Klebsiella } \\
(\mathrm{n}=192)\end{array}$ & $\begin{array}{l}\text { Acinetobacter } \\
(\mathrm{n}=62)\end{array}$ & $\begin{array}{l}\text { E. coli } \\
(\mathrm{n}=69)\end{array}$ & $\begin{array}{l}\text { Enterobacter } \\
(\mathbf{n}=\mathbf{1 8})\end{array}$ & $\begin{array}{l}\text { Entero- } \\
\text { bacteriace } \\
(\mathrm{n}=6)\end{array}$ \\
\hline \multicolumn{9}{|c|}{ Penicillin group } \\
\hline Penicillin-G & 4.2 & 9 & 1.1 & ND & ND & ND & ND & ND \\
\hline Ampicillin & ND & 9 & 83 & 43 & 17 & 68 & 16.6 & 13.3 \\
\hline Piperacillin & ND & ND & 39.4 & 7.3 & 3.2 & 5.7 & 16.6 & 5.5 \\
\hline Ticarcillin & ND & ND & 16.6 & 3.6 & 1.6 & 1.4 & ND & 5.5 \\
\hline Oxacillin & 13.8 & ND & 1.6 & 0.5 & 1.6 & ND & ND & ND \\
\hline Ampi/sulbct & ND & ND & ND & 0.5 & 1.6 & 1.4 & ND & 5.5 \\
\hline Pip/Tazo & ND & ND & 58.8 & 30.3 & 14.5 & 50.7 & 16.6 & 22.2 \\
\hline \multicolumn{9}{|c|}{ Cephalosporin group } \\
\hline Cefazoline & ND & ND & 0.5 & 4.1 & ND & 8.6 & ND & ND \\
\hline Cephalothin & 2.1 & ND & 0.5 & 0.5 & ND & ND & ND & ND \\
\hline Cefoxtin & 14.8 & ND & 2.7 & 18.3 & 4.8 & 18.8 & ND & 16.6 \\
\hline Cephotaxime & ND & ND & 18.8 & 5.7 & 1.6 & 10.1 & 16.6 & 5.5 \\
\hline Ceftazidime & ND & ND & 24.4 & 5.2 & 1.6 & 10.1 & ND & 5.5 \\
\hline Ceftriaxone & ND & ND & ND & 0.5 & ND & ND & ND & ND \\
\hline Cefepime & ND & ND & 22.2 & 5.2 & 3.2 & 14.4 & 16.6 & 5.5 \\
\hline \multicolumn{9}{|c|}{ Monobactams, Carbapenems and Glycopeptides groups } \\
\hline Aztreonam & ND & ND & ND & ND & 1.6 & 13 & 16.6 & ND \\
\hline Imipenem & ND & ND & 66.6 & 57.5 & 29 & 78.2 & 83.3 & 50 \\
\hline Meropenem & ND & ND & 41.1 & 29.3 & 27.4 & 36.2 & 66.6 & 22.2 \\
\hline Vancomycin & 90.4 & 100 & ND & 0.5 & ND & ND & ND & ND \\
\hline
\end{tabular}

Penicillins, Cephalosporins, Monobactums, Carbapenems and Glycopeptides groups, ND = Not Done

Amongst the penicillin group of antibiotics, ampicillin and piperacillin/tazobactam combination were found to be highly efficient against Pseudomonas (83\% and $58.8 \%$ respectively), E. coli ( $68 \%$ and $50.7 \%$ respectively), and
Klebsiella (43\% and $30.3 \%$ respectively). Pseudomonas was found to be more susceptible than other organisms for the penicillin group of antibiotics. 
Most of the pathogens showed low susceptibility to cephalosporin's, including fourth generation cephalosporin's. Among all the cephalosporin's, ceftazidime, a generation cephalosporin showed relatively higher efficacy against Pseudomonas (24.4\%). Vancomycin showed higher activity against Streptococcus (100\%), followed by Staphylococcus $(90.4 \%)$. Whereas, imipenem exhibited its action against Enterobacter (83.3\%), followed by E. coli (78.2) and Pseudomonas (66.6). meropenem was also found to be effective against Enterobacter (66.6\%). However, aztreonam shows relatively lower susceptibility towards pathogens (Table 3).

Chloramphenicol and tetracycline were found to be highly effective against Staphylococcus $(80.8 \%$ and 75.5
$\%$ respectively). Amikacin exhibited its activity against Pseudomonas $(83.3 \%)$ and E. coli $(68.1 \%)$. Gentamicin was highly active against Streptococcus (72.7\%). However, streptomycin and tobramicin did not show significant activity against these pathogens. Most of the fluoroquinolones and sulfonamides tested in this study did not exhibit significant efficacy against the pathogens. Linezolid was found to be highly active against Staphylococcus (89.3\%) and Streptococcus (81.8\%) whereas colistin was noted to be efficacious against Enterobacteriace (72.7\%), E. coli (62.3\%), Pseudomonas (57.2\%), Klebsiella (56\%), and Acinetobacter (48.3\%). Other antimicrobial agents like clindamicin, erythomicin, rifampicin and polymixin-B did not exhibit significant activity against any of the pathogens (Table 4).

Table 4: Susceptibility patterns of pathogens causing respiratory tract infection (broad spectrum, aminoglycoside, fluoroquinolones, sulfonamide, macrolide, lincosamide, oxazolidinones and lipopeptides groups).

\begin{tabular}{|c|c|c|c|c|c|c|c|c|}
\hline & $\begin{array}{l}\text { Staphylococcus } \\
(\mathrm{n}=94)\end{array}$ & $\begin{array}{l}\text { Streptococcus } \\
(\mathbf{n}=11)\end{array}$ & $\begin{array}{l}\text { Pseudomonas } \\
(\mathrm{n}=179)\end{array}$ & $\begin{array}{l}\text { Klebsiella } \\
(\mathrm{n}=192)\end{array}$ & $\begin{array}{l}\text { Acinetobacter } \\
(\mathrm{n}=62)\end{array}$ & $\begin{array}{l}\text { E. coli } \\
(\mathrm{n}=69)\end{array}$ & $\begin{array}{l}\text { Enterobacter } \\
(\mathrm{n}=18)\end{array}$ & $\begin{array}{l}\text { Entero- } \\
\text { bacteriace } \\
(\mathrm{n}=6)\end{array}$ \\
\hline \multicolumn{9}{|c|}{ Broad spectrum and Aminoglycoside groups } \\
\hline Chloramphenicol & 80.8 & 9 & 0.5 & 34.5 & 14.5 & 49.2 & ND & 44.4 \\
\hline Tetracycline & 75.5 & 9 & 2.7 & 44.5 & 24.1 & 30.4 & ND & 38.8 \\
\hline Amikacin & ND & 9 & 83.3 & 43.4 & 17 & 68.1 & 16.6 & 13.3 \\
\hline Gentamicin & 39.3 & 72.7 & 29.4 & 26.1 & 6.4 & 37.6 & 16.6 & 33.3 \\
\hline Streptomycin & 3.1 & 18.1 & ND & ND & ND & ND & ND & ND \\
\hline Tobramycin & 2.1 & ND & 7.2 & 7.3 & 8 & 14.4 & 16.6 & 5.5 \\
\hline \multicolumn{9}{|c|}{ Fluoroquinolones and Sulfonamide group } \\
\hline Ciprofloxacin & ND & ND & 0.5 & ND & ND & 1.4 & ND & ND \\
\hline Gatifloxacin & ND & ND & 0.5 & ND & ND & ND & 16.6 & ND \\
\hline Levofloxacin & 31.9 & 9 & 38.8 & 28.7 & 27.4 & 28.9 & 50 & 11.1 \\
\hline Norfloxacin & 1 & 9 & 0.5 & ND & 1.6 & ND & ND & ND \\
\hline Ofloxacin & 8.5 & ND & 7.7 & 3.1 & 4.8 & 7.2 & ND & 27.7 \\
\hline Trimethoprim & 8.5 & ND & ND & 10.9 & 1.6 & 13 & ND & 22.2 \\
\hline \multicolumn{9}{|c|}{ Macrolide, Lincosamide, Oxazolidinones and Lipopeptides } \\
\hline Clindamycin & 18 & 27.2 & ND & ND & ND & ND & ND & ND \\
\hline Erythromycin & 20.2 & 54.5 & ND & ND & 1.6 & ND & ND & ND \\
\hline Linezolid & 89.3 & 81.8 & ND & 0.5 & ND & ND & ND & ND \\
\hline Colistin & 4.2 & ND & 57.2 & 56 & 48.3 & 62.3 & ND & 72.7 \\
\hline
\end{tabular}

\section{DISCUSSION}

Sputum samples were the commonest specimen received in the microbiology lab for respiratory infections and contributed to $34.6 \%$ of all the samples followed by the tracheal swabs, endotracheal tube sample, pleural fluid and throat swab. Sputum samples are probably the easiest to collect, as noted in previous studies wherein $75 \%$ of the adult patients were able to produce an adequate sample of sputum for microbiological evaluation. ${ }^{12,13}$ Along with the ease of collection, sputum also has a high sensitivity $(75 \%)$ to detect the bacterial pathogens in case of a lower respiratory tract infection. ${ }^{14}$
The various organisms were isolated and cultured from these samples and their susceptibility testing was done according to Clinical and Laboratory Standards Institute Guidelines (CLSI) with the intention of assessing the discriminative prevalence of various common bacteria and to identify the local prevalent antibiotic response against the detected pathogens. ${ }^{11}$ Most commonly found bacteria in the present study were Klebsiella (30.42\%) and Pseudomonas (28.36\%) followed by Staphylococcus, Acinetobacter and E. coli. A very small number of specimens exhibited presence of Enterobacter (2.8\%), Streptococcus (1.7\%), and Enterobacteriace (0.9\%). Syed Mustaq Ahmed et al, did a study to identify the bacteriogram of all the gram negative lower respiratory 
tract infections and they found Klebsiella (41.95\%) to be the commonest bacteria causing the infection followed by Pseudomonas (26.84\%). ${ }^{15}$ Similarly, Siddalingappa et al, also studied sensitivity pattern of bacteria causing respiratory tract infections in a hospital in southern India. ${ }^{16}$ Out of 466 culture positive samples, $51.1 \%$ were positive for Klebsiella and $19.1 \%$ were positive for pseudomonas. The least prevalent bacterium was enterococci $(1.3 \%)$. Sharma $\mathrm{S}$ et al, tried to identify the common bacteria causing respiratory tract infection and its antibiotic susceptibility. ${ }^{17} \mathrm{~A}$ total of 173 individuals (94 males and 79females) sputum specimens were tested for bacterial infection. Klebsiella was the commonest bacteria isolated $26.2 \%$ followed by Streptococcus pneumonia, E. Coli, Staphylococcus aureus and Pseudomonas aeruginosa. All these three Indian studies have shown Klebsiella to be the commonest isolated bacteria and the same was found in our study as well. Pseudomonas was the second most prevalent bacteria in our study and so was it in two of the three Indian studies discussed.

Researchers have frequently stressed on the rising resistance of organisms against penicillin group of antibiotics. In fact, Akingbade et al, reported that all the Pseudomonas (100\%) and E. coli $(100 \%)$ organisms in his study were resistant to ampicillin. ${ }^{18}$ In contrast to the popular findings, amongst the penicillin group of antibiotics, ampicillin showed significant activity against Pseudomonas (83\%) followed by E. coli $(68 \%)$ in our study. Ampicillin was also highly active against Streptococcus $(90 \%)$ obtained from sputum sample. Such a contrast can probably be explained with the change in the sensitivity patterns across regions and time. Kaushik et al, had mentioned in his study that after decades of resistance of ampicillin, Salmonella is gradually getting sensitive to ampicillin again. ${ }^{19}$ Other organisms exhibited resistance towards most of the members of penicillin group of antibiotics. Combination of piperacillin/ tazobactam showed significant action against Enterobacteriace $(100 \%)$ and E. coli $(83.3 \%)$ obtained from pleural fluid.

All the bacteria isolated from different specimens showed resistance against the cephalosporin group of antibiotics. Relatively, ceftazidime and cefepime were the better choices of treatment in pseudomonas infections $(24.4 \%$ and $22.2 \%$ ). Syed Mustaq Ahmed et al, also reported ceftazidime to be a better choice amongst cephalosporin's for Pseudomonas infection (42.9\%). ${ }^{15}$ Klebsiella showed high resistance to all the cephalosporin's, with the highest resistance to cephalotin $(99.5 \%)$ and ceftriaxone $(99.5 \%)$.

All the isolated bacteria low susceptibility towards aztreonam except pathogens like Enterobacter, E. coli and Pseudomonas showed relatively higher susceptibility (83.3\%, $78.2 \%$ and $66.6 \%$ respectively) to imipenem. These findings match with the findings of Pathamanathan et al, who stated that $79.4 \%$ of Pseudomonas isolates were susceptible to imipenem. ${ }^{20}$ Imipenem also exhibited significant action against Enterobacter (100\%), E. coli (72.7\%), and Pseudomonas (63.6\%) in tracheal sample. In pleural fluid imipenem was found to be effective against Enterobacteriace (100\%), E. coli (100\%), and Klebsiella $(80 \%)$. Meropenem did not show significant activity against any of the bacterias in our study, highest activity being $66.6 \%$ against Enterobacter. This finding contradicts the findings of Urmi Jethwani et al, who reported $100 \%$ activity of meropenem against Enterobacter and Pseudomonas. ${ }^{21}$ Vancomycin in our study showed high efficacy against Streptococcus $(100 \%)$ and Staphylococcus $(90.4 \%)$ whereas Klebsiella exhibited high resistance towards it.

Broad spectrum antibiotics viz chloramphenicol and tetracycline exhibited relatively higher activity $(80.8 \%$ and $75.5 \%$ ) against Staphylococcus whereas all the other bacteria exhibited resistance against them. Such resistance against tetracycline and chloramphenicol has been frequently voiced in the past as well. ${ }^{22,23}$ Among the specimens of pleural fluid, tetracycline showed good activity against Staphylococcus (100\%) and Klebsiella $(100 \%)$ and so did chloramphenicol against Staphylococcus $(100 \%)$. Even among throat swab isolates both chloramphenicol and tetracycline showed good activity against Staphylococcus $(83.3 \%$ and $75 \%$ respectively).

Amikacin displayed relatively higher activity against Pseudomonas (83.3\%). This finding is in consensus with the finding of Pathmanathan et al, who reported that $86.6 \%$ Pseudomonas were susceptible to amikacin. ${ }^{20}$ Gentamicin also demonstrated higher activity (72.7\%) against Streptococcus. However, the respiratory pathogens exhibited resistance towards other aminoglycoside group of antibiotics.

Levofloxacin demonstrated lesser resistance towards majority of the isolates, although its highest activity being 50\% was against Enterobacter. Similar results were reported by researchers earlier. ${ }^{24,25}$ Linezolid showed significant activity against Staphylococcus and Streptococcus $(89.3 \%$ and $81.8 \%$ respectively). This finding is in consensus with the finding of Hackel $\mathrm{M}$ et al, who reported $100 \%$ sensitivity of linezolid against Staphylococcus and Streptococcus. ${ }^{25}$ Colistin showed some activity against Enterobacteriace, E. coli, Pseudomonas, Klebsiella and Acinetobacter (72.7\%, $62.3 \%, 57.2 \%, 56 \%$ and $48.3 \%$ respectively). Such a resistance of colistin against Pseudomonas was also reported by Joseph et al. $(67 \%){ }^{26}$

\section{CONCLUSION}

In our study, we found penicillins as the most efficacious antimicrobials to treat respiratory pathogens. The study reveals that the antibiotic susceptibility pattern varies across regions and timeline and hence studies examining the local susceptibility patterns should be carried out at every centre. This will arm the clinician with complete 
and updated information to select the apt antibiotic for the patients of respiratory tract infection and will reduce indiscriminate use of antimicrobials. This will help to prevent emergence of resistance strains of pathogens. The prescription of a right antibiotic, by a right doctor, for a right patient, in right doses, at the right time for right duration will be the best approach for minimizing the menace of emergence of antimicrobial resistance.

\section{Funding: No funding sources}

Conflict of interest: None declared

Ethical approval: The study was approved by the Institutional Ethics Committee

\section{REFERENCES}

1. Goel K, Ahmad S, Agarwal G, Goel P, Kumar V. A Cross Sectional Study on Prevalence of Acute Respiratory Infections (ARI) in Under-Five Children of Meerut District, India, J Community Med Health Educ 2:176.

2. Donowitz GR, Mandell GL. Acute pneumonia. In: Mandell GL, Bennett JE, Dolin R (eds): Principles and practice of infectious diseases. Churchill Livingstone, New York; 1998:619-637.

3. Andre M, Odenholt I, Schwan A, Axelsson I, Eriksson M, Hoffman M, et al. Upper respiratory tract infections in general practice: diagnosis, antibiotic prescribing, duration of symptoms and use of diagnostic tests. Scand J Infect Dis. 2002;34:8806.

4. Molstad S. Reduction in antibiotic prescribing for respiratory tract infections is needed! Scand J Prim Health Care. 2003;21:196-8.

5. Hughes JM. Epidemiology and prevention of nosocomial pneumonia. In: Remington A, Swartz C (eds): Current clinical topics in infectious diseases. McGraw-Hill, New York; 1988:241-259.

6. Jonas M, Cunha BA. Bacteremic Escherichia coli pneumonia. Archives of Internal Medicine. 1982;142:2157-9.

7. Pennington JE. Community-acquired pneumonia and acute bronchitis. In: Pennington JE (Ed): Respiratory infections: diagnosis and management. Raven Press, New York; 1988:159-170.

8. Pennington JE. Hospital-acquired pneumonia. In: Pennington JE (ed): Respiratory infections: diagnosis and management. Raven Press, New York; 1988:171186.

9. Dean AD, Dean BJ, Burton AH, Dicker RC. Epiinfoversion 5: a word processing database and statiostics programme for epidemiology on microcomputers. VSD. Inc stone mountain Ga, 1990.

10. Spellberg B, Powers JH, Brass EP, Miller LG, Edwards JE. Trends in antimicrobial drug development: Implications for the future. Clin. Infect. Dis. 2004;38:1279-86.

11. Jenkins SG, Schuetz AN. Current Concepts in Laboratory Testing to Guide Antimicrobial Therapy. Mayo Clin Proc. 2012 Mar;87(3):290-308.
12. Neill AM, Martin IR, Weir R, Anderson R, Chereshsky A, Epton MJ, et al. Community acquired pneumonia: aetiology and usefulness of severity criteria on admission. Thorax. 1996 Oct 1;51(10):1010-6.

13. Laing R, Slater W, Coles C, Chambers S, Frampton C, Jackson R, et al. Community-acquired pneumonia in Christchurch and Waikato 1999-2000: microbiology and epidemiology. The New Zealand Medical Journal. 2001 Nov;114(1143):488-92.

14. Anevlavis S, Petroglou N, Tzavaras A, Maltezos E, Pneumatikos I, Froudarakis M, et al. A prospective study of the diagnostic utility of sputum Gram stain in pneumonia. Journal of Infection. 2009 Aug 31;59(2):83-9.

15. Ahmed SM, Jakribettu RP, Meletath SK. Lower respiratory tract infections (LTRIs): An insight into the prevalence and the antibiogram of the gram negative, respiratory, bacterial agents. Journal of clinical and diagnostic research: JCDR. 2013 Feb;7(2):253.

16. Siddalingappa CM, Kalpana L, Puli S, Vasudha TK, Acharya A. Sensitivity pattern of bacteria causing respiratory tract infections in a tertiary care centre. International Journal of Basic and Clinical Pharmacology, September-October 2013;2(5):590-5.

17. Sharma S, Srivastava P, Kumar A. Respiratory Tract Infection (RTI) and its Treatment. Sch. J. App. Med. Sci. 2015;3(8E):3118-22.

18. Akingbade OA, Ogiogwa JI, Okerentugba PO, Innocent-Adiele $\mathrm{HC}$, Onoh $\mathrm{CC}$, Nwanze $\mathrm{JC}$, et al. Prevalence and Antibiotic Susceptibility Pattern of Bacterial Agents Involved in lower respiratory tract infections in Abeokuta, Ogun State, Nigeria, Report and Opinion. 2012;4(5):25-30.

19. Dwarikadhish K, Mudit M, Borade DM, Swami OC. Corresponding author. Ampicillin: Rise Fall and Resurgence. J Clin Diagn Res. 2014 May;8(5):ME01-3.

20. Pathmanathan SG, Samat NA, Mohamed R. Antimicrobial susceptibility of clinical isolates of Pseudomonas aeruginosa from a Malaysian Hospital, Malaysian Journal of Medical Sciences. 2009;16(2):27.

21. Jethwani U, Shah N, Trivedi P. Antibiotic Sensitivity Pattern of Gram Negative Bacilli Isolated from the Lower Respiratory Tract of Ventilated Patients in the Intensive Care Unit, Indian Medical Gazette - May 2014.

22. Chopra I, Marilyn R. Tetracycline Antibiotics: Mode of Action, Applications, Molecular Biology, and Epidemiology of Bacterial Resistance. Microbiol Mol Biol Rev. 2001 Jun;65(2):232-60.

23. Fernández M, Conde S, Torre AJDL, MolinaSantiago C, Ramos J, Duqueb E. Mechanisms of Resistance to Chloramphenicol in Pseudomonas putida KT2440. Antimicrob Agents Chemother. 2012 Feb;56(2):1001-9.

24. Victor O, Stanley O. Prevalence and antibiotic sensitivity of bacterial agents involved in lower 
respiratory tract infections, Int. J. Biol. Chem. Sci. April 2011;5(2):774-81.

25. Hackel M, Hawker S, Bouchillon SM, Dowzicky. monitoring the activity of linezolid against north american Staphylococcus aureus and Streptococcus pneumoniae from respiratory tract sources, T.E.S.T 2004-2009.

26. Joseph NM, Sistla S, Dutta TK, Badhe AS, Rasitha $\mathrm{D}$, Parija SC. Ventilator-associated pneumonia in a tertiary care hospital in India: role of multi-drug resistant pathogens, J Infect Dev Ctries. 2010;4(4):218-25.

Cite this article as: Dhakre S, Reddy P, Kulmi M, Goyal C. Antibiotic susceptibility pattern of bacteria isolated from patients of respiratory tract infection in a tertiary care hospital of Central India. Int J Basic Clin Pharmacol 2017;6:1740-6. 